Article

\title{
Performance Evaluation of the Urban Cadastral System in Addis Ababa, Ethiopia
}

\author{
Solomon Dargie Chekole ${ }^{1}\left(\mathbb{D}\right.$, Walter Timo de Vries ${ }^{2}\left(\mathbb{D}\right.$, Pamela Durán-Díaz ${ }^{2, *(\mathbb{C})}$ \\ and Gebeyehu Belay Shibeshi ${ }^{1}$ \\ 1 Institute of Land Administration, Bahir Dar University, 5001 Bahir Dar, Ethiopia; \\ solomon.dargie@bdu.edu.et (S.D.C.); gebeyehu.belays@bdu.edu.et (G.B.S.) \\ 2 Chair of Land Management, Department of Aerospace and Geodesy, Technical University of Munich, \\ 80333 Munich, Germany; wt.de-vries@tum.de \\ * Correspondence: pamela.duran@tum.de; Tel.: +49-89-289-257-89
}

Received: 17 November 2020; Accepted: 7 December 2020; Published: 9 December 2020

\begin{abstract}
The cadastral system is a land management and land administration tool to provide a safe and reliable real property registration system. In Ethiopia, however, the attempts to implement a reliable urban cadastral system have not been successful, which translates into a deficient land administration system. This paper is an evaluation of the performance of the urban cadastral system of Addis Ababa, based on the European Foundation for Quality Management (EFQM) excellence model. The nine criteria of the model were used as independent and dependent variables. Data were collected through interviews, Likert-type questionnaires, and focus group discussions, and validated with method-to-method technique. Qualitative and quantitative data analysis techniques (ordinal logistics regression model) were employed. In order to ascertain reliability of the data, Cronbach's alpha reliability test was performed in SPSS, and a coefficient of 0.883 was calculated, confirming that the items (questions) have relatively high internal consistency. According to the statistical result from the independent variables, the people result criteria estimated the achievement of cadastral organization at most (1.724). The societal result predicted with a coefficient of 0.281 less. This indicates that the people criterion determines more importantly than other variables. Overall, the independent variables scored the performance of the cadastral organization 24.92 out of 40 points. Findings from interviews and group discussion also confirmed that the most bottlenecks for the organizational achievement are the strategic plan, quality of leadership, bureaucratic processes, and supply of resources. Therefore, we suggest that the responsible authorities need to pay more attention to the enabler criteria (especially, the design of policy and strategy, quality of leadership, provision of resource and partnership, and the process), in order to improve the achievements of the urban cadastral system organization.
\end{abstract}

Keywords: urban land; urban cadaster; performance evaluation; land management; Ethiopia

\section{Introduction}

Land is the ultimate resource, without which, life on earth cannot be sustained [1]. The 2030 Agenda for Sustainable Development puts land at the center of accelerating and achieving the Sustainable Development Goals (SDGs) worldwide. The reason is that land plays a significant role in sustainable development due to its multiple economic, social, political, and cultural dimensions. In terms of the economic aspect, it serves as a basis for livelihood; in terms of the social aspect, land is a space for interaction; in terms of politics, land is a source of power; in terms of culture, land is a symbol of collective identity [2]. Hence, significant efforts have been invested all over the world for the correct 
management of land, including the development of reliable cadastral systems towards a secure land recordation [3,4].

The human dimension of land relates to the concepts of land governance, land management, and land administration. Although these concepts are interconnected, the land administration guideline [1] defines them separately and specifically. According to the land administration guideline, land governance is the process by which decisions are made regarding the access to and use of land, the manner in which those decisions are implemented, and the way that conflicting interests in land are reconciled. Land management is the process by which the resources of land are put to good effect; it covers all activities concerned with the management of land as a resource, both from an environmental and from an economic perspective. Land administration is the processes of recording and disseminating information about the ownership, value, use, and development of land. The land management paradigm [5] turns the cadastral system into the engine of land administration, such that cadastral information assists the functions of land tenure, land value, land use, and land development. In this way, the cadastral system becomes the core technical engine delivering the capacity to control and manage land through the four land administration functions [6]. Soto [7] and Larsson [8], Yildiz [9], and Milka [10] also recognized that accurate and reliable cadastral systems are fundamental to the economic development of any nation.

The main issue of the cadastral system is documenting land information in support of land management, and its definition varies depending on each country's circumstance and context [11,12]. In addition to this, the level of understanding and operation of cadastral systems in different countries are different due to the fact that there are different interpretations of the concept as a consequence of cultural, legal, social, and institutional differences [13]. According to Williamson [14,15], the cadastral system is the foundation and an integral component of parcel-based land information systems (LIS) that contain a record of interests in land. These systems are the central component of the land administration and land management in a state or jurisdiction [16]. Bogaerts [17] defined cadastral systems on the basis of their constituents, in which the cadastral system is a blend of a land registration and a cadaster. In the same way, Zevenbergen et al. [18] stated that a cadastral system consisted of the land registration and the cadaster. For Silva et al. [13], it is the combination of a cadaster with a spatial focus, and a land register with a legal focus including all aspects of the juridical, fiscal, and regulatory cadaster, and developed and assessed considering its political, legislative, economic, technological, and social aspects and relationships. Other scholars defined the term as a subsystem of LIS, which incorporates other subsystems; juridical, regulatory, and fiscal cadastral systems [19,20]. The cadastral template [21] defined it as the system that includes the cadaster, title registry, and the associated processes of land transfer, subdivision, and adjudication, often termed land administration. To Enemark [5,22,23], a mature cadastral system could be considered as a land administration system.

Although there is no universal definition of a cadastral system $[15,24]$, for the purposes of this research paper, it is defined as a system that refers to the operations that a cadastral organization is conducting [25].

Ethiopia, as one of the fastest developing countries in Africa, is in the process of implementing a modern urban cadastral system at the country level. In response to this, new legal and institutional frameworks have been introduced. In this regard, the Constitution of the Federal Democratic Republic of Ethiopia (FDRE) [26], under Article 40 §3, states that the mandate of administering both urban and rural land is given exclusively to the regional states. As an integral part of the land administration, the Constitution promotes the implementation of cadastral systems. Given this empowerment, the urban land is administered and managed by the legal frameworks of Proc. Nos. 721/211 [27] and 818/2014 [28]. These proclamations dictate the modality of urban land acquisition and registration, respectively. The institution undertaking these mandates is the Ministry of Urban Development, Housing and Construction [29].

In addition to these legal frameworks, a five-year strategy called the Growth and Transformation Plan (GTP) was introduced to implement the cadastral system policy. According to this strategy, 
adjudication and registration of 1.6 million and 1.2 million landholdings, respectively, across 91 cities, are planned with 200,000 adjudicated and 150,000 registered in the first year across the prioritized 23 cities [30]. Ethiopia's urban cadastral system is carried out with the goal of providing a safe and reliable real property registration system in order to foster land management which, in turn, achieves sustainable development goals (SDGs) [31]. Literature studies [16,25,32-35] have documented that Ethiopia's urban cadastral system has not been successful. In view of this, Daniel [20] argued that Ethiopia has experienced a poor urban land registration system due to the past land registration laws and also because strategic directions were not comprehensive. With regard to operational cadastral registration, Deininger [36] revealed that the early 1990s attempts of land titling in Ethiopia were unsuccessful. According to Tigistu [33], the problems and challenges faced in implementing cadastral systems basically fall within the realm of policy and legislative gaps, technical deficiencies, and inadequate institutional arrangements. Likewise, Chekole [25] reported that, though there have been many projects developed to implement the urban cadastral system, none of them could be successful. Each of these projects contained trials for implementing cadastral systems, yet these were often not complementary to earlier projects. This has resulted in overlaps, redundancies, and ill-functioning and inconsistent cadastral systems throughout the country. The aforementioned issues are results of the absence of a progress performance evaluation of the project in each project phase. In other words, there is no systematic assessment and evaluation of the strengths and weaknesses of earlier projects, and there is no systematic set of guidelines used at the start of projects.

Therefore, the purpose of this research is to investigate whether the quality of leadership, strategic planning, excellence of professional expertise, level of partnership, and mode of process affect the organizational performance of the urban cadastral system significantly or not. The underlying research question is: does quality of leadership, strategic planning, excellence of professional expertise, level of partnership, and mode of process affect the organizational performance of the urban cadastral system significantly?

\section{Methods and Materials}

\subsection{Description of the Study Area}

According to the Ethiopian constitution, Ethiopia is a federal state, administratively structured into nine regional states and two city administration councils (FDRE, 1995). Based on the nature of the research question, Addis Ababa, the capital city of Ethiopia and headquarters of the African Union, was selected as a case study for the following reasons: the city is giving urgent attention to the cadastral system; it is also the place where the urban cadastral system is being undertaken extensively compared to other regional cities; in addition, the city was selected to serve as a pilot area for the rest of the regional cities.

\subsection{Data Obtained and Used}

To achieve the intended objective of the study, both primary and secondary data sources were used. Primary data were collected through physical observation and semi-structured interviews. Secondary data were collected from published journals, books, and grey literature (reports, proclamations, regulations, directives, standards, and legislations).

\subsection{Experimental Design}

The study applied a true experimental research design that relies on statistical analysis to determine the extent to which cadastral system organizational achievements are met. To do so, data were collected in all (ten) sub-cities of Addis Ababa. Likert-type open and close-ended questionnaires were administered to a sample of 150 land administration and management professionals, who were selected purposively. Additionally, ten cadastral system directors from all sub-cities provided their responses in focus group discussions consisting of 6-8 experts in each sub-city. 


\subsection{Questionnaire Design}

Both close-ended and open-ended questions (see Appendix A) were designed and administered to the sampled participants. Respondents were requested to rate their level of satisfaction for 33 closed questions raised for 9 categories ( 5 enablers and 4 results in the EFQM excellence model) related to their organizational circumstances. Benchmarking this model, a number of scholars [37-43] have evaluated the perceptions of respondents based on Likert scale data. The questionnaire contained both positively and negatively worded items to identify random responses. Close-ended responses are bounded between 1-5 scores and represent "Not at all satisfied", "Slightly satisfied", "Moderately satisfied", "Very satisfied", and "Completely satisfied".

\subsection{Methods and Theoretical Framework}

The research applied desk review and case study research methods. The desk review focuses on exploring and looking into existing literature on cadastral systems performance evaluation. Case study was used to get real-life situations and better understandings into the detailed actions of cadastral system.

The research has benchmarked Connel's [44] theory of change to guide the overall theoretical aspect of cadastral systems. Given that the origin of the theory of change lies in the field of monitoring and evaluation, it is an adequate framework for an urban cadastral system performance evaluation in order to determine how much of the intended result of a given intervention is achieved as a result. The EFQM Excellence model is used as an analytical tool to comprehensively measure and evaluate the performance of the urban cadastral system (see Figure 1). The intervention criterion evaluates what and how an organization does in response to the achievement that the organization aimed for.

The enabling interventions are leadership, strategy, people, resource and partnership, and process, which, when effectively implemented, aids the organization to achieve the intended result. For the sake of analysis, these enablers and results are independent and dependent variables, respectively, which can be quantified within the concept of cadastral systems. Each criterion has its own weight, which needs to be considered. The sum of all criteria accounts an overall weight of $100 \%$.

Thus, the overall processes of the theory of change follow a cause-effect relationship as in the Logical model (a hypothesized description of the chain of causes and effects leading to an outcome of interest). It depicts the relationship between organizational activities and its intended effects. When evaluating an urban cadastral system, enablers such as policies and strategies, leadership, excellence of professional expertise, partnerships, and processes are benchmarked as enabling requirements, while organizational results (business results) are benchmarked as organizational achievements.

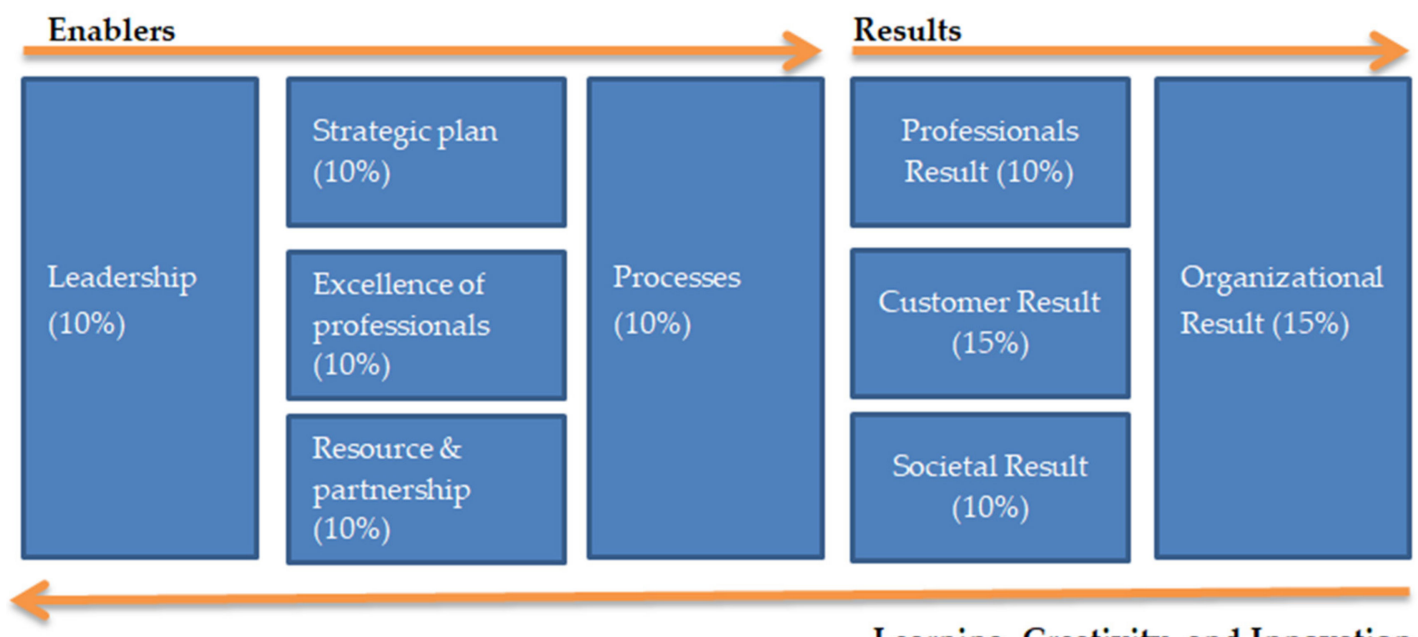

Learning, Creativity, and Innovation

Figure 1. EFQM excellence model (Source: adapted from EFQM [45]). 


\subsection{Statistical Methods}

After collecting the required data, Cronbach's alpha (a measure of internal consistency) was used to check how closely related a set of items (questions) are. Cronbach's alpha, which ensures that either the response given from each respondent was consistent or not, was used to validate and ensure that the data is reliable. Based on the collected data, qualitative and quantitative data analysis techniques were employed. In undertaking the quantitative analysis, a regression model was used to investigate the extent to which independent variables affect the dependent variable. The correlations among the independent variables were also investigated to see which variable has more effects. Data collected from interviews, open-ended questionnaires, observations, and focus group discussions were described qualitatively.

In order to make sure that the collected data are correct, consistent, and useful for its accuracy and reliability against respondents, the data were verified through Cronbach's alpha in SPSS. The alpha coefficient for this study is 0.883 , suggesting that the items have relatively high internal consistency. A reliability coefficient of 0.70 or higher is considered "acceptable" in most research studies. After ensuring that the data reliability was correct and certain, Equation (1) was used to calculate the overall organizational achievement of the cadastral system. The equation represents the influence of independent variables $X$ on the dependent variable $Y$, which is a fundamental concept in ordinal regression.

$$
Y=\beta_{0}+\beta_{1} X_{1} W_{1}+\beta_{2} X_{2} W_{2}+\ldots+\beta_{n} X_{n} W_{n}
$$

where $Y$ is the dependent variable (overall organizational performance), $\beta_{0}$ is the intercept, $\beta_{n}$ is coefficients (estimates), $X_{n}$ is the mean value of independent variables, and $n$ refers to the number of independent variables, which in this case is 8 . The intercept for ordinal regression model is zero since it starts from the origin.

Table 1 shows basic descriptive statistical information about the response statistics. The minimum and maximum numbers are bounded between 1 and 5 to represent level of satisfaction. The Mean describes the average of the responses; median explains the value separating the higher half from the lower half of a response, while the mode explains the number that appears most frequently.

Table 1. Response statistics of the questionnaire $(n=150)$.

\begin{tabular}{cccccccccc}
\hline & Strategy & Leadership & People & $\begin{array}{c}\text { Resource \& } \\
\text { Partnership }\end{array}$ & Process & $\begin{array}{c}\text { People } \\
\text { Result }\end{array}$ & $\begin{array}{c}\text { Customer } \\
\text { Result }\end{array}$ & $\begin{array}{c}\text { Societal } \\
\text { Result }\end{array}$ & $\begin{array}{c}\text { Organizational } \\
\text { Result }\end{array}$ \\
\hline \multirow{2}{*}{ N $\quad \begin{array}{c}\text { Valid } \\
\text { Missing }\end{array}$} & 150 & 150 & 150 & 150 & 150 & 150 & 150 & 150 \\
0 & 0 & 0 & 0 & 0 & 0 & 0 & 150 \\
\hline & Mean & 3.12 & 3.25 & 2.97 & 3.95 & 3.97 & 3.37 & 2.65 & 3.41 \\
Median & 3.00 & 3.20 & 3.00 & 4.00 & 4.00 & 3.25 & 3.00 & 3.00 \\
Mode & 2.75 & 3.40 & 3.00 & 4.00 & 4.00 & 3.25 & 3.00 & 3.00 \\
\hline
\end{tabular}

Assumptions of Ordinal logistic regression model: ordinal logistic regression (often just called "ordinal regression") is used to predict an ordinal dependent variable given one or more independent variables. There are four assumptions to validate this model. (1) Dependent variables should be measured at the ordinal level; (2) independent variables must be treated as either continuous or categorical, they cannot be treated as ordinal variables; (3) two or more independent variables that should not be highly correlated with each other (no multicollinearity); (4) each independent variable has an identical effect at each cumulative split of the ordinal dependent variable.

Regression model fitting information: Since the collected data from questionnaire are in the form of order (rank) through Likert scale, ordinal regression model was performed to extract meaningful information. This type of regression model has five conditions to be fulfilled.

Model fitting: this is the measure of how well the model fits the data. The significance level of alpha is 0.05 , which limits the level of significance value. The result from this model is 0.00 (See Table 2), which is less than the common alpha level of 0.05 , which indicates that it is statistically significant, telling that the model gives better predictions. The statistical significance indicates that changes in the independent variables (enablers) correlate with shifts in the dependent variable (organizational performance). 
Goodness of fit: The goodness of fit of a statistical model describes how well it fits a set of observations. Measures of goodness of fit typically summarize the discrepancy between observed values and the values expected under the model in question. The significance value for the goodness of fit (Pearson) is 1 (see Table 2), which is greater than the common alpha level of 0.05 , which indicates that it is statistically significant and suggests that the model fits the data very well.

Table 2. Regression model fitting information that justifies appropriateness of the model.

\begin{tabular}{|c|c|c|c|c|}
\hline \multicolumn{5}{|c|}{ Model Fitting Information } \\
\hline Model & -2 Log Likelihood & Chi-Square & $\mathrm{df}$ & Sig. \\
\hline Intercept Only & 485.218 & & & \\
\hline Final & 309.316 & 175.902 & 43 & 0.00 \\
\hline \multicolumn{5}{|c|}{ Link function: Logit. } \\
\hline \multicolumn{5}{|c|}{ Goodness-of-Fit } \\
\hline & Chi-Square & $\mathrm{df}$ & & \\
\hline Pearson & 558.504 & 851 & & \\
\hline Deviance & 309.316 & 851 & & \\
\hline \multicolumn{5}{|c|}{ Link function: Logit. } \\
\hline \multicolumn{5}{|c|}{ Pseudo R-Square } \\
\hline Cox and Snell & & 0.690 & & \\
\hline Nagelkerke & & 0.719 & & \\
\hline McFadden & & 0.363 & & \\
\hline \multicolumn{5}{|c|}{ Link function: Logit. } \\
\hline \multicolumn{5}{|c|}{ Test of Parallel Lines ${ }^{\text {a }}$} \\
\hline Model & -2 Log Likelihood & Chi-Square & $\mathrm{df}$ & Sig. \\
\hline Null Hypothesis & 363.724 & & & \\
\hline General & $338.524^{b}$ & $25.200^{c}$ & 40 & 0.967 \\
\hline
\end{tabular}

The null hypothesis states that the location parameters (slope coefficients) are the same across response categories.

${ }^{a}$ Link function: Logit. ${ }^{b}$ The log-likelihood value cannot be further increased after maximum number of step-halving.

${ }^{c}$ The Chi-Square statistic is computed based on the log-likelihood value of the last iteration of the general model.

Validity of the test is uncertain.

Pseudo $\mathrm{R}^{2}$ : This statistic indicates the percentage of the variance in the dependent variable (organizational performance) that the independent variables (enablers) explain collectively. If $\mathrm{R}^{2}$ (Nagelkerke) is greater than 0.7 , it indicates that $70 \%$ of the independent variables explain the dependent variable, which in this case is 0.719 .

Test of parallel line: this is the test according to the assumption of proportional odds. This is a key assumption in ordinal regression. The assumption is that the effects of any explanatory variables are consistent (proportional) across the different thresholds (by thresholds we mean the splits between each pair of categories of your ordinal outcome variable). In other words, that the explanatory variables have the same effect on the odds regardless of the threshold.

\subsection{Uncertainties and Shortcomings of the Study}

Since the study was conducted in the capital city of Ethiopia, the result may not be certain to make generalization to other cities of the country due to geographical differences. Due to the COVID-19 situation, some of the interviews with key informants were made through virtual communication, which may limit the study in getting detailed information compared with physical presence with the interviewee. In addition to the EFQM excellence model, it would have been better if the study had benchmarked other evaluation frameworks. 


\section{Results}

\subsection{Socio-Economic Profile of the Respondents}

Age and Marital Status: The age of respondents affects their views about the particular problems; usually age indicates level of maturity of individuals, in that sense age becomes more important to examine the response. The perceptions and attitudes of the person can also differ by the marital status due to the acquired responsibilities through marriage. Table 3 shows that $64.7 \%$ of the respondents were within the range of $20-30$ years; $30 \%$ were within the range of $31-40$ years; and 5.3\% were within the range of $41-50$. This indicates that the majority $(64.7 \%)$ of the respondents were professionals within the age of 31-40 years. An overwhelming number of the respondents $(73.3 \%)$ were married and the remaining $(26.7 \%)$ were unmarried.

Education and educational background: education is one of the most important characteristics that might affect a person's attitudes and way of looking and understanding any particular social phenomena. The educational background of respondents also affects the credibility of the responses. A considerable number of respondents (80.7\%) were BSc graduates and $19.3 \%$ were MSc graduates who are working in the cadastral system organization. In relation to this, most of the experts $(70 \%)$ are land administration graduates, while lawyers, geomatics and civil engineers, IT, geographers, and related fields share the remaining 30\% (see Table 3). It is believed that the organization has recruited appropriate professionals who can accomplish the intended missions of the cadastral system.

Experience and level of income: experience gives firsthand knowledge of what is actually working in the industry. In Table 3, the majority of the respondents $(78.7 \%)$ have about 4 years of experience, while the remaining $21.3 \%$ fall within the range of $8-11$ years. It was ensured that the respondents were all very experienced staff members who are (or have been) involved in all aspects of land administration activities. The collective responses can thus be considered significant. Respondents' level of income plays an important role in shaping the economic conditions of an individual, which, in turn, is likely to have a bearing on the responses to a posed problem. Most of the respondents $(79.3 \%)$ were earning a monthly income of between 12,001 and 15,000 birr, $12.7 \%$ of the respondents earn between 15,001 and 18,000 birr, while the rest ( $8 \%$ ) earn above 18,000 birr.

Table 3. Profile of the respondents.

\begin{tabular}{|c|c|c|c|c|c|}
\hline Characteristics & Frequency & Percent & Characteristics & Frequency & Percent \\
\hline \multicolumn{3}{|c|}{ Age } & \multicolumn{3}{|c|}{ Educational Background } \\
\hline $20-30$ & 97 & 64.7 & Land Administration & 105 & 70 \\
\hline $31-40$ & 45 & 30 & Geomatics & 7 & 4.7 \\
\hline $41-50$ & 8 & 5.3 & Law & 14 & 9.3 \\
\hline \multicolumn{3}{|c|}{ Marital Status } & Geography & 6 & 4 \\
\hline Single & 40 & 26.7 & Civil Engineering & 7 & 4.7 \\
\hline Married & 110 & 73.3 & IT & 8 & 5.3 \\
\hline \multicolumn{3}{|c|}{ Education } & Others & 3 & 2 \\
\hline $\mathrm{BSc}$ & 121 & 80.7 & \multicolumn{3}{|c|}{ Income (ETB) } \\
\hline MSc & 29 & 19.3 & $12,001-15,000$ & 119 & 79.3 \\
\hline \multicolumn{3}{|c|}{ Experience (years) } & $15,001-18,000$ & 19 & 12.7 \\
\hline $4-7$ & 118 & 78.7 & $>18,000$ & 12 & 8 \\
\hline $8-11$ & 32 & 21.3 & & & \\
\hline
\end{tabular}




\subsection{Correlation Results}

Correlation (see Table 4) explains the level of association between involved variables. According to the assumption of the ordinal regression model, the level of association between or among independent variables should not be greater than 0.7 .

Table 4. Correlation results among variables.

\begin{tabular}{|c|c|c|c|c|c|c|c|c|c|}
\hline & $\begin{array}{l}\text { Policy \& } \\
\text { Strategy }\end{array}$ & Leadership & People & $\begin{array}{l}\text { Resource \& } \\
\text { Partnership }\end{array}$ & Process & $\begin{array}{l}\text { People } \\
\text { Result }\end{array}$ & $\begin{array}{c}\text { Customer } \\
\text { Result }\end{array}$ & $\begin{array}{c}\text { Societal } \\
\text { Result }\end{array}$ & $\begin{array}{r}\text { Original } \\
\text { Result }\end{array}$ \\
\hline Policy \& Strategy & 1 & & & & & & & & \\
\hline Leadership & 0.371 & 1 & & & & & & & \\
\hline Resource \& Partnership & 0.1 & 0.423 & 0.206 & 1 & & & & & \\
\hline Process & 0.062 & 0.253 & 0.146 & 0.662 & 1 & & & & \\
\hline People Result & -0.081 & 0.013 & 0.037 & 0.036 & 0.04 & 1 & & & \\
\hline Customer Result & 0.001 & 0.054 & 0.027 & -0.003 & -0.004 & 0.042 & 1 & & \\
\hline
\end{tabular}

\subsection{Ordinal Logistic Regression Model Estimation Result}

Ordinal logistic regression model was used to predict the relationship between the ordinal outcome and independent variables towards urban cadastral system level of excellence. From Table 5, it can be noted that policy and strategy, leadership, resource and partnership, process, and customer result are variables which are not statistically significant $(p$ values $>0.05)$.

Table 5. Coefficients that estimates the influence of independent variables on the dependent.

\begin{tabular}{cccccc}
\hline Variables & Estimate $(\beta)$ & $\operatorname{Exp}(\beta)$ & Std. Error & df & $p$ Value \\
\hline Policy \& Strategy & 0.354 & 1.425 & 0.476 & 1 & 0.457 \\
Leadership & 0.489 & 1.631 & 0.653 & 1 & 0.454 \\
People & 1.120 & 3.065 & 0.510 & 1 & 0.037 \\
Resource \& Partnership & 0.508 & 1.662 & 0.735 & 1 & 0.489 \\
Process & 0.540 & 1.716 & 0.681 & 1 & 0.875 \\
People Result & 1.724 & 5.607 & 0.618 & 1 & 0.000 \\
Customer Result & 1.657 & 5.244 & 0.377 & 1 & 0.085 \\
Societal Result & 0.281 & 1.324 & 0.312 & 1 & 0.000 \\
\hline
\end{tabular}

Based on this evidence, we retain the null hypothesis and reject the alternative hypothesis. To interpret the result, cadastral system policy and strategy, quality of leadership, provided resource and partnership, existing process to deliver services, and the satisfaction result of the customer have no significant effect on the organizational achievements. This does not mean that those variables do not affect, rather they affect the performance of the cadastral organization with less significance. For instance, the quality of cadastral policy and strategy affects the organization with 0.354 amounts. When the independent variable (policy and strategy) increases with 1 unit, the dependent variable (organizational result) will increase with 0.354 amounts.

On the other hand, People, People Result, and Societal Result are statistically significant ( $p$ values $<0.05$ ), which in this case reject the null hypothesis and accept the alternative hypothesis. Based on significance values ( $p$ values), People, People Result, and Societal Result have a significant effect on the success of the organizational achievements.

Table 6 provides the results of the ordinal logistic regression model. According to the results, all thresholds are statistically significant at the significance level of 0.05 . 
Table 6. Estimated coefficients, assigned weights, and mean response rate.

\begin{tabular}{ccccc}
\hline Independent Variables & $\begin{array}{c}\text { Calculated } \\
\text { Coefficients or } \\
\text { Estimates }(\boldsymbol{\beta})\end{array}$ & $\begin{array}{c}\text { Assigned } \\
\text { Weight }(\mathbf{W})\end{array}$ & $\begin{array}{c}\text { Mean } \\
(\boldsymbol{X}) \text { Values }\end{array}$ & $\begin{array}{c}\text { Dependent } \\
\text { Variable } \\
\text { (Calculated) }\end{array}$ \\
\hline Policy \& Strategy & 0.354 & 1.0 & 3.12 & \\
Leadership & 0.489 & 0.8 & 3.25 & \\
People & 1.120 & 0.9 & 2.97 & \\
Resource \& Partnership & 0.508 & 0.9 & 3.95 & $Y=24.916$ \\
Process & 0.540 & 1.4 & 3.97 & \\
People Result & 1.724 & 0.9 & 3.37 & \\
Customer Result & 1.657 & 2.0 & 2.65 & \\
Societal Result & 0.281 & 0.6 & 3.41 & \\
\hline
\end{tabular}

The column of Calculated Coefficients or Estimates ( $\beta$ ) provides the values for $\beta_{1}$ to $\beta_{n}$ for this equation; the column Assigned Weight (taken from the EFQM excellence model) presents the weights for the respective independent variables, and the column Mean (X) Values presents the average values for all respondents in each variable. Expressed in terms of the variables used in this table, the regression equation for the overall performance of the organization is calculated based on Equation (1).

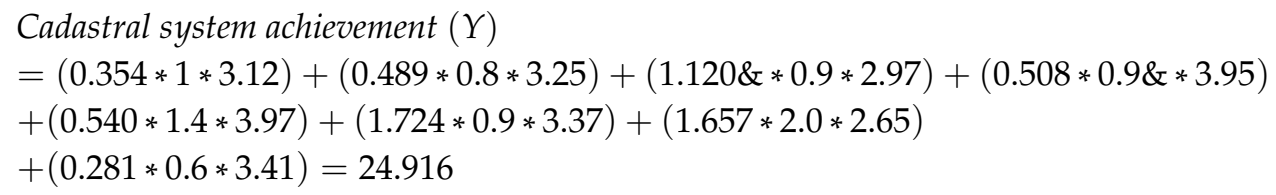

\subsection{Interview and Focus Group Discussion Results}

The interview was made (see Table 7) for directors of the urban cadastral system agency in each of the 10 sub-cities. Apart from this, focus group discussions among land administration experts were conducted to crosscheck and validate the responses from the directors.

Table 7. Interview score from the cadastral system directors of ten sub-cities.

\begin{tabular}{|c|c|c|c|c|c|c|}
\hline Statements & Very Poor & Poor & Fair & Good & Excellent & Total \\
\hline Quality of policy and strategic plan & & 8 & 2 & & & 10 \\
\hline Quality of organizational leadership & & 8 & 2 & & & 10 \\
\hline Excellence of expertise (People) & & & 4 & 4 & 2 & 10 \\
\hline Provision of resource & & 8 & 2 & & & 10 \\
\hline Quality of organizational (process) & & 8 & 2 & & & 10 \\
\hline People Result & & & 5 & 4 & 1 & 10 \\
\hline Customer Result & & 4 & 4 & 2 & & 10 \\
\hline Societal Result & & 1 & 5 & 4 & & 10 \\
\hline
\end{tabular}

\section{Discussion}

The EFQM Excellence Model is based on the logical assumption that excellence in enablers will lead to superior results, and thus leadership drives policy and strategy, people management, and partnerships and resources, and these three elements influence the results through suitable processes [45]. As a quality model, the EFQM Excellence Model explains, through its enabler criteria, the areas that the organization should consider as input to improve its results, as well as the result indicators that must be achieved. In this regard, the EFQM Excellence model provides a pattern of relationships both between enablers and results, and between the criteria. Empirical evidence shows that significant relationships exist between the result elements, where results on one level contribute to outcomes on others $[46,47]$. The excellence model assumes that customer results, people results, and society results will, together, ultimately infer organizational performance. Research on the 
relationship between enablers and results indicates that weaknesses in leadership can affect people, customer, societal, and key organizational results [48,49].

Based on the findings of this research, reliability of the empirical data was tested through Cronbach's alpha (0.883) and passed the required level of significance, which is 0.7 . This result can be compared with the result by Carlos [50], Cronbach's alpha of 0.71 . Hence, the result confirmed that the items (questions) have relatively high internal consistency. The selected regression model (ordinal logistics regression model) was proved to be a good fit with our data and passed the required level of significance (see Table 2). In addition to this, there was an assumption for the ordinal regression model to be met in relation to correlation, which states that correlation among independent variables should not be highly correlated. On the basis of this assumption, it can be observed from the Table 4 that there is a positive and negative correlation between independent variables. If the correlation is greater than 0.7 , it is said to be highly correlated (multicollinearity). Accordingly, the assumption is met on the basis of this benchmark. The maximum correlation among independent variables is 0.662 , for partnership and process variables, while the lowest correlation is -0.003 for partnership and customer results. These statistics indicate that the ordinal regression is an appropriate model to analyze and interpret the data.

We also considered the results of model fitting, goodness of fit, Pseudo $\mathrm{R}^{2}$ and test of parallel line. Nagelkerke's $\left(R^{2}\right)$ statistics showed that the independent variables explain about $71.9 \%$ of the variations in the outcomes. All those statistics confirm that the model is a good fit to explain the outcome. Based on these test results, estimates (coefficients) presented in Table 5 are calculated. Those estimates or coefficients of the independent variables (Strategy, Leadership, People, Partnership, Process, People Result, Customer Result, and Societal Result) determine the dependent variable (organizational performance). Coefficients are the change in the response associated with a one-unit change of the independent, all other independents being held constant. In short, these parameters are values for the regression equation to predict the dependent variable.

The performance of an urban cadastral system is measured through 8 independent variables, each with a satisfaction score between 1 (not at all satisfied) and 5 (completely satisfied), thus the sum of the overall performance of the cadastral organization could achieve a minimum of 8 and a maximum of 40 . Since the performance of an urban cadastral system is measured only through the eight independent variables, there is no intercept $\left(\beta_{0}\right)$ that can be added with the rest of the estimated coefficients. Hence, based on the results obtained in Table 6, each independent variable predicted the dependent variable in different weights. In the case of the urban cadastral system of Addis Ababa, people result and customer result were estimated with the highest scores among all the independent variables, which are 1.724 and 1.657, respectively, while strategy and leadership were estimated with the lowest values, which are 0.354 and 0.489 , respectively. Accordingly, people result was affected the most compared to the rest of the variables, and on the other hand, policy and strategy has less effect on the overall organizational result. Thus, the high value of the regression estimation parameter implies that there is strong causal relationship between the independent and dependent variables. Therefore, the overall performance of the organization is evaluated out of 40 . Based on the findings of this research, the urban cadastral system organization scored 24.196 out of 40 . In percentage, the Addis Ababa urban cadastral system organization has an overall performance of $62.3 \%$.

With regard to interviews, ten cadastral sub-city directors were interviewed to respond to questions related to the performance of their organization in relation to EFQM criteria. They responded that the most bottlenecks for the achievement of their organization are strategic planning, quality of leadership, bureaucratic processes, and supply of resources. In this regard, most of the respondents (80\%) agreed with this idea, in that it was not designed in a way that responds to the existing circumstances of the city.

In addition to this, results from the focus group discussion confirm that most problems emanate from the strategic plan, supply of resources, and leadership skill. Comparing these responses with the interview and questionnaire, it measures the reality of the organization. 


\section{Conclusions}

The objective of this paper was to evaluate the performance (achievement) of the urban cadastral system of Ethiopia, using the case of Addis Ababa, based on the EFQM excellence model. The main idea behind the research is about cadastral information, which is a basis for property valuation, land-use planning, land tenure, and land development. Cadastral information offers accurate inventories of land parcels, provides a true and exact description of the legal situation of rights in land, provides a standardized database for management of public lands, serves as a basis for valuation and taxation, and serves as evidence of ownership for legal cases. Thus, the research benefits land administration stakeholders with these and other related land administration and management functions. This study was conducted based on an international performance evaluation model called EFQM. In this regard, the research is unique in that there is no study conducted in Addis Ababa using this type of evaluation framework/model. It is an empirical study on the urban cadastral system of Addis Ababa using primary data based on direct observation. Hence, it can serve as literature to the scientific community. The research will benefit the land administration and management stakeholders (governmental organizations, NGOs, private sector, etc.) to be aware of the experiences of the urban cadastral system of Addis Ababa. This, in turn, makes the stakeholders well informed in their decision making. Apart from that, some of the interviews with key informants were made through webinar, which may limit the study in getting in-depth information compared with physical presence with the interviewee. The findings showed that the urban cadastral system organization achieves an overall performance of $62.3 \%$ with major problems identified in the strategic plan, supply of resources, leadership skill, and the processes bureaucracy.

Policy implications: land administration and management proclamations, regulations, directives, and standards are issued by policy makers. Designing these laws needs well-informed decision makers. Decision makers within the domain of the land governance theme should be aware of what the reality on the ground looks like and about the achievements of the cadastral system organization for their financial planning. Hence, this research provides insights for policy makers in making well-informed decisions. In addition to this, we recommend that the responsible cadastral authorities need to pay serious attention to the enabler criteria (especially, the design of policy and strategy, quality of leadership, provision of resource and partnership, and the process), in order to improve the performance of urban cadastral system achievements.

Future works: this research has conducted the performance of the urban cadastral system organization in Addis Ababa using the EFQM Excellence model. Other scholars in the field may undertake studies using other evaluation frameworks apart from EFQM.

Author Contributions: Conceptualization, S.D.C., W.T.d.V., P.D.-D., and G.B.S.; methodology S.D.C.; validation, S.D.C., W.T.d.V., P.D.-D., and G.B.S.; formal analysis, S.D.C.; investigation, S.D.C.; resources, S.D.C.; data curation, S.D.C.; writing-original draft preparation, S.D.C., W.T.d.V., P.D.-D., and G.B.S.; writing-review and editing S.D.C., W.T.d.V., P.D.-D., and G.B.S.; visualization, S.D.C.; supervision, W.T.d.V., P.D.-D., and G.B.S.; funding acquisition, P.D.-D. All authors have read and agreed to the published version of the manuscript.

Funding: This research received external funding from DAAD, in the form of a Short Term Research Scholarship for In-Country/In region Scholarship holders, grant numer 57520399. The Article Processing Charges of this research were funded by the Technical University of Munich (TUM).

Acknowledgments: The authors would like to acknowledge the editor in chief and anonymous reviewers for their critical review and constructive comments in improving the paper. The authors would also like to thank the Technical University of Munich (TUM), DAAD, and the Institute of Land Administration (ILA) of Bahir Dar University (BDU) for providing supporting materials. Special thanks to Walter Dachaga for proofreading this paper.

Conflicts of Interest: The authors declare no conflict of interest.

\section{Appendix A. Evaluation Criteria of the Cadastral System Organization}

Within the framework of the EFQM excellence model, nine criteria were developed and distributed to the respondents in the form of Likert scale questions. The concept behind this research is that people 
results, customer results, and societal results are achieved through leadership-driving cadastral policy and strategy, people, partnership and resources and processes, which leads ultimately to excellence in cadastral organizational performance achievements. There are included sub-criteria, though broad questions are only presented here.

1. Leadership: how do leaders develop mission and vision, and implement them via appropriate plans for urban cadastral system organization?

2. Strategy: does the urban cadastral system organization implement their mission and vision by developing a stakeholder focused strategy?

3. People: does the urban cadastral system organization value its people and create a culture that allows the mutually beneficial achievement of organizational goals?

4. Partnership and resource: how does the urban cadastral system organization plan and manage external partnerships, suppliers, and internal resources in order to support their strategy, policies and the effective operation of processes?

5. Process: does the urban cadastral system organization design, manage, and improve processes to generate quality services for customers and stakeholders?

6. People results: does the urban cadastral system organization achieve and sustain outstanding results that meet or exceed the needs and expectations of their people?

7. Customer results: does the urban cadastral system organization achieve and sustain outstanding results that meet or exceed the needs and expectations of their customers?

8. Societal results: does the urban cadastral system organization achieve and sustain outstanding results that meet or exceed the needs and expectations of relevant stakeholders within society?

9. Organizational results: does the urban cadastral system organization achieve and sustain outstanding results that meet or exceed the needs and expectations of their business stakeholders?

\section{References}

1. UNECE. Land Administration Guidelines. With Special Reference to Countries in Transition; United Nations: New York, NY, USA, 1996; ISBN 92-1-116644-6.

2. Dale, P.; McLaren, R. GIS in land administration. In Geographical Information Systems: Principles, Techniques, Management and Applications, Abridged Edition; Longey, P., Ed.; John Wiley \& Sons, Inc.: New York, NY, USA, 2005; pp. 859-875.

3. Krigsholm, P.; Zavialova, S.; Riekkinen, K.; Ståhle, P.; Viitanen, K. Understanding the future of the Finnish cadastral system-A Delphi study. Land Use Policy 2017, 68, 133-140. [CrossRef]

4. Dawidowicz, A.; Źróbek, R. A methodological evaluation of the Polish cadastral system based on the global cadastral model. Land Use Policy 2018, 73, 59-72. [CrossRef]

5. Enemark, S. Understanding the Land Management Paradigm. In Proceedings of the Fig COM 7 Symposium on Innovative Technologies for Land Administration, Madison, WI, USA, 19-25 June 2005.

6. Plimmer, F.; Williamson, I.; Enemark, S.; Wallace, J.; Rajabifard, A. Land Administration for Sustainable Development; ESRI Press Academic: Redlands, CA, USA, 2010; ISBN 978-1-58948-041-4.

7. De Soto, H. The Mystery of Capital. Why Capitalism Triumphs in the West and Fails Everywhere Else, 1st ed.; Basic Books: New York, NY, USA, 2006; ISBN 978-0465016150.

8. Larsson, G. Land Registration and Cadastral Systems. Tools for Land Information and Management; Longman Scientific \& Technical: Harlow, UK, 1991; ISBN 0582089522.

9. Yildiz, O.; Coruhlu, Y.E.; Biyik, C. Registration of agricultural areas towards the development of a future Turkish cadastral system. Land Use Policy 2018, 78, 207-218. [CrossRef]

10. Mika, M. Modernisation of the Cadastre in Poland as a tool to improve the land management and administration process. Surv. Rev. 2020, 52, 224-234. [CrossRef]

11. Kocur-Bera, K. Data compatibility between the Land and Building Cadaster (LBC) and the Land Parcel Identification System (LPIS) in the context of area-based payments: A case study in the Polish Region of Warmia and Mazury. Land Use Policy 2019, 80, 370-379. [CrossRef] 
12. Polat, Z.A.; Alkan, M.; Sürmeneli, H.G. Determining strategies for the cadastre 2034 vision using an AHP-Based SWOT analysis: A case study for the Turkish cadastral and land administration system. Land Use Policy 2017, 67, 151-166. [CrossRef]

13. Silva, M.A.; Stubkjær, E. A review of methodologies used in research on cadastral development. Comput. Environ. Urban Syst. 2002, 26, 403-423. [CrossRef]

14. Williamson, I.P. Cadasters and Land Information Systems in Common Law Jurisdictions. Surv. Rev. 1985, 28, 186-195. [CrossRef]

15. Williamson, I.P. Cadastral and land information systems in developing countries. Aust. Surv. 1986, 33, $27-43$. [CrossRef]

16. Williamson, I.; Henssen, J. Land Registration, Cadaster and its Interaction: A World Perspective. In Proceedings of the XIXth International Congress of Surveyors, Helsinki, Finland, 10-19 June 1990.

17. Bogaerts, T.; Zevenbergen, J. Cadastral systems-Alternatives. Comput. Environ. Urban Syst. 2001, 25, 325-337. [CrossRef]

18. Zevenbergen, J.; Augustinus, C.; Antonio, D.; Bennett, R. Pro-poor land administration: Principles for recording the land rights of the underrepresented. Land Use Policy 2013, 31, 595-604. [CrossRef]

19. Hull, S.; Whittal, J. Towards a Framework for Assessing the Impact of Cadastral Development on Land Rights-Holders; International Federation of Surveyors: Copenhagen, Denmark, 2016.

20. Tadesse, D. Reflections on the situation of urban cadaster in Ethiopia. In Proceedings of the Africa Local Government Action Forum (ALGAF) Phase VI, Addis Ababa, Ethiopia, 7 April 2006.

21. Rajabifard, A.; Steudler, D.; Aien, A.; Kalantari, M. The Cadastral Template 2.0, from Design to Implementation. In Proceedings of the FIG Congress 2014 Engaging the Challenges, Enhancing the Relevance, Kuala Lumpur, Malaysia, 16-21 June 2014.

22. Enemark, S. Land Administration and Cadastral Systems in Support of Sustainable Land Governance-A Global Approach. In Proceedings of the 3rd Land Administration Forum for the Asia and Pacific Region, Tehran, Iran, 24-26 May 2009.

23. Enemark, S.; Williamson, I.; Wallace, J. Building modern land administration systems in developed economies. J. Spat. Sci. 2005, 50, 51-68. [CrossRef]

24. Steudler, D. (Ed.) Cadastre 2014 and Beyond; FIG: Copenhagen, Denmark, 2014; ISBN 978-87-92853-12-7.

25. Chekole, S.D.; de Vries, W.T.; Shibeshi, G.B. An Evaluation Framework for Urban Cadastral System Policy in Ethiopia. Land 2020, 9, 60. [CrossRef]

26. Constitution of the Federal Democratic Republic of Ethiopia; FDRE: Addis Ababa, Ethiopia, 1995.

27. Urban Land Lease Holding Proclamation; Proclamation No. 721/2011; Negarit Gazetta; Federal Democratic Republic of Ethiopia: Addis Ababa, Ethiopia, 2011.

28. Urban Landholding Adjudication and Registration Proclamation 818/2014; House of People Representatives: Addis Ababa, Ethiopia, 2014.

29. Strategic Plan of 2020-2025 for Ministry of Urban Development and Construction; Ministry of Urban Development and Construction: Addis Ababa, Ethiopia, 2020.

30. Growth and Transformation Plan II (GTP II): Federal Urban Land and Land Related Registration and Information Agency; FDRE: Addis Ababa, Ethiopia, 2015.

31. Enemark, S. Fit-For-Purpose Land Administration. Joint FIG/World Bank Publication; FIG: Copenhagen, Denmark, 2014; ISBN 978-87-92853-10-3.

32. Deininger, K.; Selod, H.; Burns, A. The Land Governance Assessment Framework: Identifying and Monitoring Good Practice in the Land Sector; World Bank: Washington, DC, USA, 2012.

33. Tigistu, G.A. Experience and future direction in Ethiopian rural land administration. In Proceedings of the Conference on Land and Poverty, Washington, DC, USA, 18-20 April 2011.

34. Fairlie, K.; Burns, T.; Zhang, Y.; Adlington, G.; Tamrat, I.; Shibeshi, G.; McDowell, A.; Kebede, S.; Zelul, A. Establishing a Legal Cadaster for Good Governance in Ethiopia: Identifying Bottlenecks and Steps towards Scale-Up 2017. In Proceedings of the Annual World Bank Land and Poverty Conference, Washington, DC, USA, 20-24 March 2017.

35. Rajabifard, A. Sustainable Development Goals Connectivity Dilemma; CRC Press: Boca Raton, FL, USA, 2019; ISBN 9780429290626.

36. Deininger, K.; Ali, D.A.; Holden, S.; Zevenbergen, J. Rural Land Certification in Ethiopia: Process, Initial Impact, and Implications for Other African Countries. World Dev. 2008, 36, 1786-1812. [CrossRef] 
37. Laarakker, P.; DeVries, W.; Wouters, R. Land Registration and Cadaster, One or Two Agencies?: Stage 2 of the research. In Proceedings of the World Bank Conference on Land and Poverty, Washington, DC, USA, 14-18 March 2016.

38. Kambiz, S.; Hamidreza, A. Mathematical model to rank companies provider EFQM with context-dependent data envelopment analysis (case study: Iran auto industry). Aust. J. Basic Appl. Sci. 2011, 7, 295-302.

39. Nabitz, U.; Klazinga, N.; Walburg, J. The EFQM excellence model: European and Dutch experiences with the EFQM approach in health care. European Foundation for Quality Management. Int. J. Qual. Health Care 2000, 12, 191-201. [CrossRef]

40. Turisova, R.; Sinay, J.; Pacaiova, H.; Kotianova, Z.; Glatz, J. Application of the EFQM Model to Assess the Readiness and Sustainability of the Implementation of I4.0 in Slovakian Companies. Sustainability 2020, 12, 5591. [CrossRef]

41. Vykydal, D.; Folta, M.; Nenadál, J. A Study of Quality Assessment in Higher Education within the Context of Sustainable Development: A Case Study from Czech Republic. Sustainability 2020, 12, 4769. [CrossRef]

42. Pohle, A.; Blind, K.; Neustroev, D. The Impact of International Management Standards on Academic Research. Sustainability 2018, 10, 4656. [CrossRef]

43. Wang, G.; Liu, H.; Li, H.; Luo, X.; Liu, J. A Building Project-Based Industrialized Construction Maturity Model Involving Organizational Enablers: A Multi-Case Study in China. Sustainability 2020, 12, 4029. [CrossRef]

44. Connell, J.P. New Approaches to Evaluating Community Initiatives. Concepts, Methods, and Contexts; Aspen Institute: Queenstown, MD, USA, 1995; ISBN 0-89843-167-0.

45. EFQM. European Foundation Quality Management: European Foundation Quality Management (EFQM) Excellence Model. Available online: https://www.efqm.org/ (accessed on 30 October 2019).

46. Oakland, J.S.; Oakland, S. The links between people management, customer satisfaction and business results. Total Qual. Manag. 1998, 9, 185-190. [CrossRef]

47. Sadikoglu, E.; Olcay, H. The Effects of Total Quality Management Practices on Performance and the Reasons of and the Barriers to TQM Practices in Turkey. Adv. Decis. Sci. 2014, 2014, 1-17. [CrossRef]

48. Eskildsen, J.K.; Dahlgaard, J.J. A causal model for employee satisfaction. Total Qual. Manag. 2000, 11, 1081-1094. [CrossRef]

49. Eskildsen, J.K. Identifying the vital few using the European Foundation for Quality Management model. Total Qual. Manag. 1998, 9, 92-94. [CrossRef]

50. Llusar, J.C.B.; Tena, A.B.E.; Roca-Puig, V.; Beltrán-Martín, I. An empirical assessment of the EFQM Excellence Model: Evaluation as a TQM framework relative to the MBNQA Model. J. Oper. Manag. 2009, 27, 1-22. [CrossRef]

Publisher's Note: MDPI stays neutral with regard to jurisdictional claims in published maps and institutional affiliations.

(C) 2020 by the authors. Licensee MDPI, Basel, Switzerland. This article is an open access article distributed under the terms and conditions of the Creative Commons Attribution (CC BY) license (http://creativecommons.org/licenses/by/4.0/). 